\title{
Analysis of 2009 International Energy Conservation Code Requirements for Residential Buildings in Mesa, Arizona
}

R Lucas

March 2011

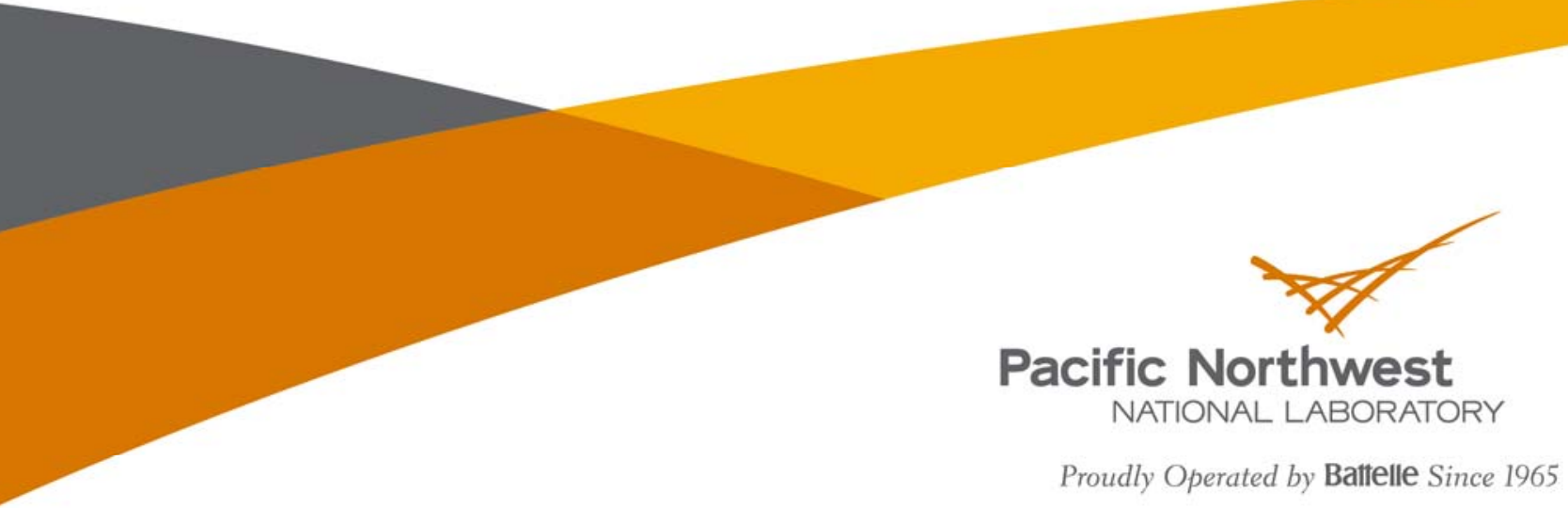




\title{
DISCLAIMER
}

This report was prepared as an account of work sponsored by an agency of the United States Government. Neither the United States Government nor any agency thereof, nor Battelle Memorial Institute, nor any of their employees, makes any warranty, express or implied, or assumes any legal liability or responsibility for the accuracy, completeness, or usefulness of any information, apparatus, product, or process disclosed, or represents that its use would not infringe privately owned rights. Reference herein to any specific commercial product, process, or service by trade name, trademark, manufacturer, or otherwise does not necessarily constitute or imply its endorsement, recommendation, or favoring by the United States Government or any agency thereof, or Battelle Memorial Institute. The views and opinions of authors expressed herein do not necessarily state or reflect those of the United States Government or any agency thereof.

\author{
PACIFIC NORTHWEST NATIONAL LABORATORY \\ operated by \\ BATTELLE \\ for the \\ UNITED STATES DEPARTMENT OF ENERGY \\ under Contract DE-AC05-76RL01830
}

Printed in the United States of America
Available to DOE and DOE contractors from the Office of Scientific and Technical Information, P.O. Box 62, Oak Ridge, TN 37831-0062; ph: (865) 576-8401 fax: (865) 576-5728
email: reports@adonis.osti.gov

\begin{abstract}
Available to the public from the National Technical Information Service, U.S. Department of Commerce, 5285 Port Royal Rd., Springfield, VA 22161 ph: (800) 553-6847 fax: $(703) 605-6900$ email: orders@ntis.fedworld.gov online ordering: http://www.ntis.gov/ordering.htm
\end{abstract} This document was printed on recycled paper. 
PNNL-20230

\section{Analysis of 2009 International Energy Conservation Code Requirements for Residential Buildings in Mesa, Arizona}

R Lucas

March 2011

Prepared for

U.S. Department of Energy

under Contract DE-AC05-76RL01830

Pacific Northwest National Laboratory

Richland, Washington 99352 



\section{Summary}

The 2009 International Energy Conservation Code (IECC) contains several major improvements in energy efficiency over the 2006 IECC and the 2003 IECC. The notable changes are

- Improved duct sealing verified by testing the duct system

- Increased duct insulation

- Improvement of window U-factors from 0.40 to 0.35

- Efficient lighting requirements.

An analysis of these changes resulted in estimated annual energy cost savings of \$145 a year for an average new house compared to the 2003 IECC. This energy cost saving decreases to $\$ 125$ a year for the 2009 IECC compared to the 2006 IECC. Construction cost increases (per home) for complying with the 2009 IECC are estimated at \$1256 relative to the 2003 IECC and \$800 for 2006 IECC. Home owners will experience an annual cost savings of about $\$ 80$ a year by complying with the 2009 IECC because reduction to energy bills will more than compensate for increased mortgage payments and other costs. 


\section{Table of Contents}

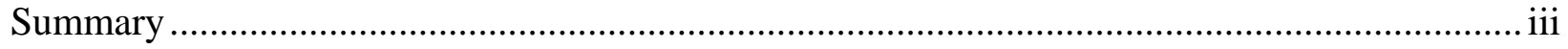

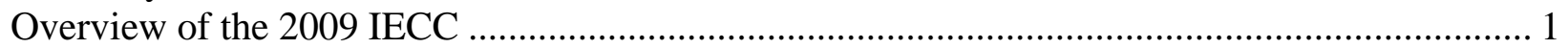

Main Difference between the 2006 IECC and the 2009 IECC ................................................. 3

Main Difference between the 2003 IECC and the 2006 IECC ................................................ 5

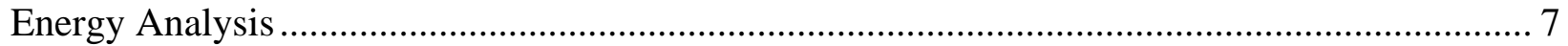

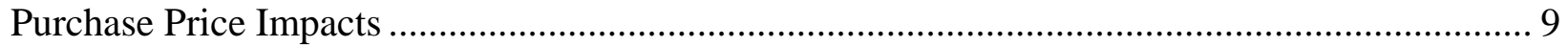

Window U-factor and SHGC Improvement .................................................................. 9

Improved Duct Sealing Verified by Testing .................................................................. 9

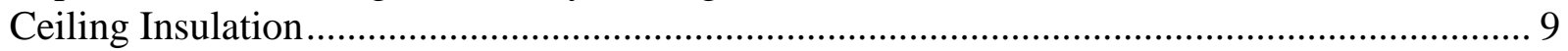

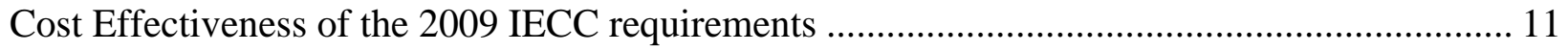

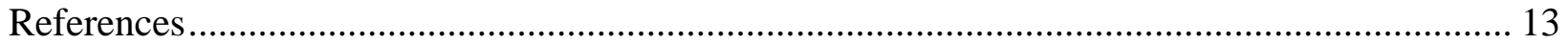




\section{Tables}

Table 1 Envelope Requirements in the 2009 IECC ............................................................. 1

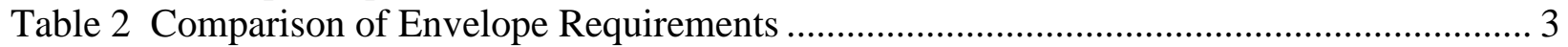

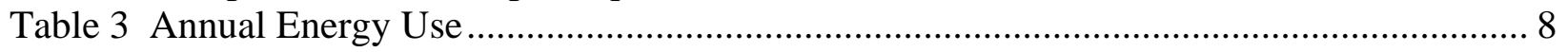

Table 4 Annual Energy Costs and Percentage Savings Vs. 2006 IECC..................................... 8

Table 5 Annual Energy Costs and Percentage Savings Vs. 2003 IECC.................................... 8

Table 6 Impacts to Consumers’ Cash Flow from Compliance with 2009 IECC........................ 12 


\section{Overview of the 2009 IECC}

The IECC scope includes residential single-family housing and multifamily housing three stories or less above-grade, intended for permanent living (hotel/motel is not "residential"). The code applies to new buildings and additions/alterations/renovations/repairs. Key envelope requirements are shown in Table 1.

Table 1 Envelope Requirements in the 2009 IECC

\begin{tabular}{|c|c|}
\hline Ceiling & R-30 \\
\hline Skylight U-factor & U-0.75 \\
\hline Window U-factor & U-0.65 \\
\hline Wood Frame Wall & R-13 \\
\hline $\begin{array}{c}\text { Fenestration Solar Heat } \\
\text { Gain Coefficient (SHGC) }\end{array}$ & 0.30 \\
\hline Mass Wall & R-4/6 ${ }^{(1)}$ \\
\hline Floor & R-13 \\
\hline Basement Wall & No insulation \\
\hline Slab & No insulation \\
\hline Crawlspace Wall & No insulation \\
\hline
\end{tabular}

(1) The second R-value applies if more than one-half the insulation is on the interior of the mass wall.

Additional requirements in the 2009 IECC:

- Building envelope must be caulked and sealed.

- Supply ducts in attics must be insulated to R-8. Return ducts in attics and all ducts in crawlspaces, unheated basements, garages, or otherwise outside the building envelope must be insulated to R-6.

- All ducts must be sealed and either:

o verified by pressure testing - the duct system has to be tested and the air leakage out of ducts must be kept to an acceptable maximum level.

o installed entirely within the building thermal envelope - testing is not required if all ducts are inside the building thermal envelope (for example in heated basements), although the ducts still have to be sealed.

- Piping for hydronic (boiler) heating systems must be insulated to R-3. 
- Less insulation is allowed for mass walls and more insulation is required for steel framing.

- $50 \%$ of the lighting "lamps" (bulbs, tubes, etc.) in a building must be high efficacy. Compact fluorescents qualify; standard incandescent bulbs do not.

- Standard I-code administrative requirements (inspections, documentation) apply.

- A certificate must be posted near the electrical panel listing insulation levels and other energy-efficiency measures.

Exemptions/allowances from prescriptive measures:

- One door and $15 \mathrm{ft}^{2}$ of window area are exempt.

Mandatory requirements:

Windows can never exceed an area-weighted average solar heat gain coefficient (SHGC) of 0.50. The 2009 IECC also identifies a set of other requirements that are strictly "mandatory" that must be done in all buildings, such as building envelope and duct sealing.

Compliance paths:

The 2003, 2006, and 2009 IECC all effectively contains three alternative compliance paths.

1) Prescriptive measures. This is considered the simplest path. These requirements do not vary by building size, shape, window area, or other features. The 2009 IECC has a single table of requirements for insulation R-values and window and door U-factors and SHGC. There is a corresponding U-factor table that permits compliance of less common component types (e.g., structural insulated panels), albeit without any cross-component trade-offs.

2) Total building envelope UA (U-factor multiplied by area). This is the path predominantly used by the REScheck ${ }^{\mathrm{TM}}$ software. Based on the prescriptive U-factor table, it allows trade-offs whereby some energy-efficiency measures can fall below code requirements if balanced by other measures that exceed code requirements.

3) Simulated performance (requires software programs). This path allows compliance if the home has a calculated annual energy consumption (or energy cost) equal to or less than that of a standard reference design that just meets the code's prescriptive requirements. This path allows for crediting energy-efficiency measures not accounted for in the other paths, such as renewable energy measures. The 2009 performance path differs from previous editions of the IECC in that it allows no trade-off credit for the use of highefficiency space heating, space cooling, or water heating equipment. 


\section{Main Difference between the 2006 IECC and the 2009 IECC}

The 2006 IECC has the same format (including the same climate zones) and many of the same requirements as the 2009 IECC. The 2006 IECC differs from the 2009 IECC resulting from the four amendments described above. In addition to this, other major differences between the 2006 IECC and the 2009 IECC are listed below

- The 2006 IECC requires ducts to be sealed but not to a specific leakage rate verified by testing, as is required in the 2009 IECC (if any ducts are outside the building envelope).

- $50 \%$ of the lighting "lamps" (bulbs, tubes, etc.) in a building have to be high efficacy in the 2009 IECC; the 2006 IECC has no lighting requirement. Compact fluorescents qualify; standard incandescent bulbs do not.

- Trade-off credit can no longer be obtained for high-efficiency heating, ventilation, and air conditioning (HVAC) equipment in the 2009 IECC. For example, if a high-efficiency furnace is used, no reduction in wall insulation is allowed. (This will have a substantial impact on the flexibility allowed by the REScheck ${ }^{\mathrm{TM}}$ software and other energy performance analysis tools.)

- A number of thermal envelope requirements have improved in the 2009 IECC. These are highlighted in Table 2.

Table 2 Comparison of Envelope Requirements

\begin{tabular}{|c|c|c|c|}
\hline & $\begin{array}{c}\text { 2003 IECC (15\% } \\
\text { or lower window } \\
\text { area) }\end{array}$ & 2006 IECC & 2009 IECC \\
\hline \hline Ceiling & 19 & 30 & 30 \\
\hline Skylight U-factor & 0.75 & 0.75 & 0.75 \\
\hline Fenestration U-factor & 0.75 & 0.75 & 0.65 \\
\hline Fenestration SHGC & 0.40 & 0.40 & 0.30 \\
\hline Wood Frame Wall & 11 & 13 & 13 \\
\hline Mass Wall & Varies & $4 / 6^{(1)}$ & $4 / 6^{(1)}$ \\
\hline Floor & 11 & 13 & 13 \\
\hline Basement Wall & No Requirement & No Requirement & No Requirement \\
\hline Slab & No Requirement & No Requirement & No Requirement \\
\hline Crawlspace Wall & R-5 & No Requirement & No Requirement \\
\hline
\end{tabular}

(1) The second R-value applies if more than one-half the insulation is on the interior of the mass wall.

Other changes in the 2009 IECC compared to the 2006 IECC: 
- R-3 pipe insulation on hydronic distribution systems (increased from R-2)

- Stricter area limits on door exemptions

- Improved (more detailed) air-sealing language

- Pool covers are required for heated pools. 


\section{Main Difference between the 2003 IECC and the 2006 IECC}

The 2003 IECC has a different format and different climate zones from the 2006 IECC (and 2009 IECC). The prescriptive envelope requirements vary by the window area percentage of the residence. Table 2 shows the 2003 IECC prescriptive requirements for a home with 12 to 15\% window area (as a percent of total wall area), which is typical for many starter or mid-level homes. For homes with a high window area of 20 to 25\%, the 2003 IECC requirements become more stringent, with a maximum allowable glazing-factor of only U-0.55 and ceiling insulation of R-30. In contrast, the 2006 and 2009 IECC requirements shown in Table 2 apply to all homes regardless of the window area percentage.

Other than this difference in format, the 2003 IECC has generally consistent requirements with the 2006 IECC, and the differences listed above between the 2006 and 2009 IECC also apply to the 2003 IECC compared to the 2009 IECC. 


\section{Energy Analysis}

A brief energy analysis was conducted comparing the energy use resulting from compliance with the different versions of the IECC. The EnergyGauge ${ }^{\mathrm{TM}}$ software (Florida Solar Energy Center 1999) was used to determine the energy impacts of changes in envelope requirements. EnergyGauge $^{\mathrm{TM}}$ utilizes the DOE-2 energy simulation software developed by the U.S. Department of Energy (DOE). (Use of specific brands or trade names is for research purposes only and does not constitute an endorsement of these items.)

Three sets of buildings were simulated: one with energy-efficiency levels set to the prescriptive requirements of the 2003 IECC, 2006 IECC, and the 2009 IECC. All inputs other than the changes in energy-efficiency levels were identical in the three sets of simulations.

The analysis assumed a two-story, single-family house with a conditioned floor area of 2,400 $\mathrm{ft}^{2}$ with a slab-on-grade foundation. It was assumed that the house had 9-ft high ceilings, a ceiling area (bordering the unconditioned attic) of $1,200 \mathrm{ft}^{2}$, a gross exterior wall area of 2,380 $\mathrm{ft}^{2}$, and a window area of $360 \mathrm{ft}^{2}$ equally oriented north, south, east, and west. This window area corresponds to $15 \%$ of the wall area, which impacts the requirements of the 2003 IECC, as discussed above.

Heating with a 78\% annual fuel utilization efficiency (AFUE) natural gas furnace (\$1.42/therm) and cooling with a 13 seasonal energy efficiency ratio (SEER) central electric air conditioning $(\$ 0.116 / \mathrm{kWh})$ were assumed. All fuel prices were obtained from the DOE Energy Information Administration and are residential prices specific for Arizona. Natural gas costs are for the heating season; and therefore, the January 2010 cost was used. ${ }^{\text {a }}$ Electricity for air conditioning is the August 2010 state average cost. ${ }^{\mathrm{b}}$

Table 3 shows the estimated annual energy usage for a home built to the requirements of the 2003 IECC, 2006 IECC and the 2009 IECC. For heating energy use with a natural gas furnace, the first value is natural gas energy use; the second value is fan electricity use for distributing the heated air. Tables 4 and 5 show these impacts in terms of energy cost, including the savings per house that results from meeting the improved requirements in the 2009 IECC. Total savings and percent savings includes space heating and cooling (air conditioning) only. Tons of $\mathrm{CO}_{2}$ savings per home per year are also shown in these tables.

\footnotetext{
a http://www.eia.gov/dnav/ng/hist/n3010mo3m.htm

b http://www.eia.doe.gov/cneaf/electricity/epm/table5_6_a.html
} 
Table 3 Annual Energy Use

\begin{tabular}{|c|c|c|c|c|c|}
\hline \multicolumn{2}{|c|}{2003 IECC } & \multicolumn{2}{|c|}{2006 IECC } & \multicolumn{2}{|c|}{2009 IECC } \\
\hline Heating & Cooling (kWh) & Heating & $\begin{array}{c}\text { Cooling } \\
(\mathrm{kWh})\end{array}$ & Heating & $\begin{array}{c}\text { Cooling } \\
(\mathrm{kWh})\end{array}$ \\
\hline $\begin{array}{c}9.3 \mathrm{MBtu}+ \\
54 \mathrm{kWh}\end{array}$ & 7754 & $\begin{array}{c}8.5 \mathrm{MBtu}+ \\
49 \mathrm{kWh}\end{array}$ & 7668 & $\begin{array}{c}8.2 \mathrm{MBtu}+ \\
47 \mathrm{kWh}\end{array}$ & 7372 \\
\hline
\end{tabular}

Table 4 Annual Energy Costs and Percentage Savings Vs. 2006 IECC

\begin{tabular}{|c|c|c|c|c|c|c|}
\hline \multicolumn{4}{|c|}{ Annual Energy Cost (\$) } & \multirow{2}{*}{\multicolumn{3}{|c|}{$\begin{array}{c}\text { Total savings } \\
2009 \text { IECC vs. } \\
2006 \text { IECC } \\
\end{array}$}} \\
\hline \multicolumn{2}{|c|}{2006 IECC } & \multicolumn{2}{|c|}{2009 IECC } & & & \\
\hline Heating & Cooling & Heating & Cooling & $\begin{array}{c}\text { Savings } \\
(\$ / y r)\end{array}$ & $\begin{array}{l}\text { Percent } \\
\text { Savings } \\
\end{array}$ & $\begin{array}{c}\text { Tons of } \mathrm{CO}_{2} \\
\text { Saved }\end{array}$ \\
\hline$\$ 127$ & $\$ 805$ & $\$ 110$ & $\$ 697$ & $\$ 125$ & $13.4 \%$ & 0.21 \\
\hline
\end{tabular}

Table 5 Annual Energy Costs and Percentage Savings Vs. 2003 IECC

\begin{tabular}{|c|c||c|c||c|c|c||}
\hline \multicolumn{3}{|c||}{ Annual Energy Cost (\$) } & \multicolumn{3}{c|}{$\begin{array}{c}\text { Total savings } \\
\text { 2009 IECC vs. } \\
\text { 2003 IECC }\end{array}$} \\
\cline { 1 - 3 } Heating & Cooling & Heating & Cooling & $\begin{array}{c}\text { Savings } \\
(\$ / y r)\end{array}$ & $\begin{array}{c}\text { Percent } \\
\text { Savings }\end{array}$ & $\begin{array}{c}\text { Tons of } \mathrm{CO}_{2} \\
\text { Saved }\end{array}$ \\
\hline$\$ 138$ & $\$ 814$ & $\$ 110$ & $\$ 697$ & $\$ 145$ & $15.2 \%$ & 0.31 \\
\hline
\end{tabular}

Improved duct sealing was assumed to save $10 \%$ of the heating and cooling costs. This impact was not included in the simulation analysis, but rather was applied directly to the simulation results. The 10\% savings was assumed in the state analysis report (Lucas and Cole 2009). However, it is important to emphasize actual savings will vary depending on many factors, including how well ducts are currently sealed in the absence of any testing requirements.

High-efficacy lighting requirements were not included in Tables 3, 4, and 5 because savings attributable to the lighting requirements in the IECC will become less relevant because Federal law requires improved light bulbs in 2012 to 2014. However, if efficient lighting is assumed to increase from $10 \%$ to $50 \%$ of all lighting within the home, lighting energy use decreases by $26 \%$.

Also, wall insulation is assumed to be R-13 for 2003 IECC compliance, even though that code allows R-11 because R-13 fiberglass batts are the most commonly used product for insulating wood frame walls regardless of the code requirement. 


\section{Purchase Price Impacts}

The more stringent requirements in the 2009 IECC will increase the cost of new homes. The construction cost impacts assumed in this analysis are documented below.

\section{Window U-factor and SHGC Improvement}

It is difficult to accurately assign a cost to the U-factor improvement to U-0.65 and the SHGC improvement to 0.30 for the 2009 IECC. A cost of $\$ 1$ per square foot of window area is estimated for this improvement ( EPA and DOE 2009).

\section{Improved Duct Sealing Verified by Testing}

The IECC duct sealing requirement has two cost components. First is the cost of testing the installed ducts using duct pressurization equipment. Hammon and Modera (1999) estimate a cost of $\$ 131$ to $\$ 163$ for testing, and suggest costs will be even lower in a mature market. The Journal of Light Construction (Uniacke 2003) quotes a cost of \$220 for testing. The Appalachian State study (2010) reports a cost of $\$ 175$ to $\$ 250$. It is important to note that the 2009 IECC allows the ducts to be tested by the HVAC contractor immediately after the ducts are installed. This should help keep both costs and construction timeline impacts to a minimum. A cost of $\$ 200$ for duct testing was assumed for this analysis.

There is a one-time cost of purchasing a "duct blaster" and related equipment for pressurizing the duct system and testing the air leakage. Frank Spevak of the Energy Conservatory (a manufacturer of blower doors) verbally reported a price of $\$ 1800$ for this equipment. Another source reports a cost of $\$ 1500-2000$ (Wray et al. 2003). This cost was not included in the economic analysis results below because the cost per home should be minimal because the equipment can be used many times.

Hammon and Modera (1999) estimate a cost of \$214 for materials and labor for improved duct sealing. Research for the 2011 Energy Star Home estimates a cost of $\$ 0.10 / \mathrm{ft}^{2}$ of home floor area for improved sealing (EPA 2009). For the $2400 \mathrm{ft}^{2}$ home analyzed here, this is a cost of $\$ 240$, which was the value assumed in this analysis.

\section{Ceiling Insulation}

The 2003 IECC requires R-19 insulation; the 2006 and 2009 IECC requires R-30 cavity insulation. A cost increase of $\$ 0.38 / \mathrm{ft}^{2}$ or $\$ 456$ for the entire ceiling based on 2011 RS Means published cost data (includes overhead and profit) (RS Means 2011) is assumed in this analysis. 


\section{Cost Effectiveness of the 2009 IECC requirements}

Total construction cost increases from the 2009 IECC assumed in this report are $\$ 1256$ relative to the 2003 IECC and $\$ 800$ relative to the 2006 IECC.

Because most houses are financed, consumers will be very interested in the financial impacts of buying a home that complies with the 2009 IECC requirements. Mortgages spread the payment for the cost of a house over a long period of time. In this analysis, a 30-year fixed-rate mortgage was assumed. It was also assumed that homebuyers will deduct the interest portion of the payments from their income taxes.

The financial and economic parameters required for input to this analysis are summarized below. These parameters are used to calculate the costs and benefits of increased energy efficiency from the homeowner's perspective.

- New-home mortgage parameters:

- $\quad 5.0 \%$ mortgage interest rate (fixed rate)

- $\quad$ points and loan fees equal to $1 \%$ of the mortgage amount

- 30-year loan term

- $\quad 20 \%$ down payment

- $\quad$ Other rates and economic parameters:

- $\quad 28 \%$ marginal Federal income tax

- $\quad 4 \%$ state income tax

- $1 \%$ property tax.

Table 6 shows the impacts to consumers' cash flow resulting from the improvements in the 2009 IECC. The upfront costs include the down payment, points, and loan fees. The savings from income tax deductions for the mortgage interest will slowly decrease over time. The annual values shown in the table are for the first year. Table 6 also includes increases in annual property taxes because of the higher assessed house values. The net annual cash flow includes energy costs, mortgage payments, mortgage tax deductions, and property taxes but not the upfront costs. The time to positive cash flow is under 4 years for the improvements in the 2009 IECC compared to the 2003 IECC and 2 years compared to the 2006 IECC. This includes all costs and benefits, including the down payment and other upfront costs. 
Table 6 Impacts to Consumers' Cash Flow from Compliance with 2009 IECC

\begin{tabular}{||l|c|c||}
\hline & \multicolumn{2}{|c|}{ Cost Impact } \\
\hline \hline & 2003 to 2009 IECC & 2006 to 2009 IECC \\
\hline $\begin{array}{l}\text { Down payment and other } \\
\text { upfront costs }\end{array}$ & $\$ 265$ & $\$ 169$ \\
\hline Annual energy savings & $\$ 145$ & $\$ 125$ \\
\hline Annual mortgage increase & $\$ 76$ & $\$ 48$ \\
\hline $\begin{array}{l}\text { Net annual cash flow } \\
\text { savings }\end{array}$ & $\$ 78$ & $\$ 85$ \\
\hline
\end{tabular}




\section{References}

Appalachian State. 2010. Development and Implementation of an Improved Residential Energy Code for North Carolina. Asheville, North Carolina.

Environmental Protection Agency. 2009. ENERGY STAR Qualified Homes 2011 Savings \& Cost Estimate Summary. Washington, D.C. See "Economic Impacts" link at: Accessed 12/2/2010.

http://www.energystar.gov/index.cfm?c=bldrs_lenders_raters.nh_comment_period_docs

Environmental Protection Agency and U.S. Department of Energy. 2009. Energy Star Qualified New Home Version 3 Guidelines. Economic Impacts (5/5/2009). Washington, D.C. Accessed $12 / 2 / 2010$.

http://www.energystar.gov/index.cfm?c=bldrs_lenders_raters.nh_comment_period_docs.

Florida Solar Energy Center. 1999. EnergyGauge USA: A Residential Building Energy Simulation Design Tool. Cocoa, Florida.

Hammon, RW, and MP Modera. 1999. "Improving the Efficiency of Air Distribution Systems in New California Homes-Updated Report.” Consol. Stockton, California.

Lucas, RG and PC Cole. 2009. Impacts of the 2009 IECC for Residential Buildings at State Level. PNNL-18545. Prepared by Pacific Northwest National Laboratory, Richland, Washington, for the U.S. Department of Energy. http://www.energycodes.gov/publications/techassist.stm. Accessed 1/19/2011.

RS Means, 2011. Residential Cost Data. 30th Edition. Kingston, Massachusetts.

Uniacke, M. 2003. “Pressure-Testing Ductwork.” Journal of Light Construction. April.

Wray et al. 2003. Instrumented Home Energy Rating and Commissioning. LBNL-52216. Lawrence Berkeley National Laboratory, Berkeley, California.

http://epb.lbl.gov/publications/lbnl-52216.pdf Accessed 1/19/2011. 


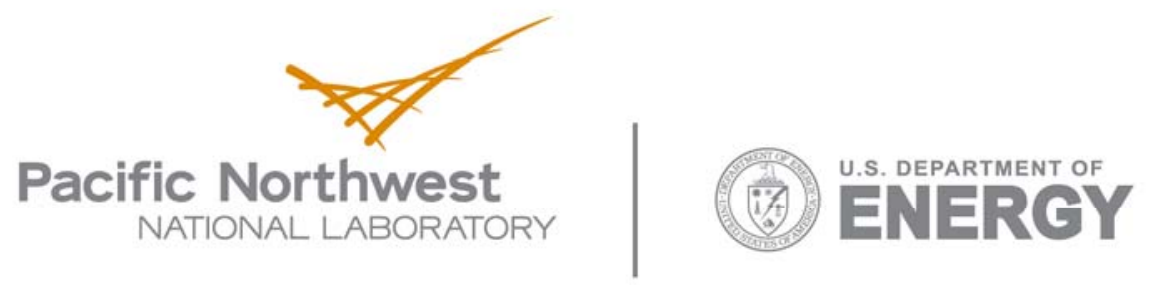

902 Battelle Boulevard

P.O. Box 999

Richland, WA 99352

1-888-375-PNNL (7665)

www.pnl.gov 